\title{
Seasonal Variations of Heavy Metals Concentration in Abattoir Dumping Site Soil in Nigeria
}

\author{
${ }^{1}$ YAHAYA, M.I.; ${ }^{2}$ MOHAMMAD, S. ; ${ }^{3}$ ABDULLAHI, B. K. \\ ${ }^{1 .}$ Chemistry Department, College of Basic and Advanced Studies, Yauri, Kebbi State, Nigeria. \\ 2. Department of Pure and Applied Chemistry. Usmanu Danfodiyo University, Sokoto, Nigeria \\ 3. Geography Department, College of Basic and Advanced Studies, Yauri ,Kebbi State, Nigeria \\ Corresponding Author: Email-mansur_yahaya@yahoo.com (YAHAYA M.I) Mobile- +23407037928905
}

\begin{abstract}
Assessment of seasonal variation in concentration of the heavy metals- $\mathrm{Co}, \mathrm{Cr}, \mathrm{Cu}, \mathrm{Fe}, \mathrm{Mn}, \mathrm{Ni}, \mathrm{Pb}$ and $\mathrm{Zn}$ - in Abattoir dump site soil at Yauri, Nigeria, was undertaking during the two major seasons of Nigeria. This was done to determine the environmental pollution status of the soil at the dump site. Soil samples $(0-15 \mathrm{~cm})$ collected during the 2007/2008 rainy and dry seasons were treated and digested using microwave acid digestion methods. The heavy metal concentrations were determined with Atomic Absorption spectrophotometer (AAS). The mean levels range of $\mathrm{Co}, \mathrm{Cr}, \mathrm{Cu}, \mathrm{Fe}, \mathrm{Mn}, \mathrm{Ni}, \mathrm{Pb}$ and $\mathrm{Zn}$ were $13.2-30.02 \mathrm{mg} / \mathrm{kg}, 59.14-102.50 \mathrm{mg} / \mathrm{kg}, 59.32-$ $96.13 \mathrm{mg} / \mathrm{kg}, 2569-4130 \mathrm{mgkg}, 263.01-608.11 \mathrm{mg} / \mathrm{Kg}, 36.21-107.13 \mathrm{mg} / \mathrm{kg}, 15.60-30.09 \mathrm{mg} / \mathrm{kg}$ and $56.31-$ $92.50 \mathrm{mg} / \mathrm{kg}$ for dry seasons and $10.13-22.76 \mathrm{mg} / \mathrm{kg}, 49.96-\quad 89.46 \mathrm{mg} / \mathrm{kg}, 49.12-73.08 \mathrm{mg} / \mathrm{kg}, 23330.02$ $3671.14 \mathrm{mg} / \mathrm{kg}, 249.72-561.03 \mathrm{mg} / \mathrm{kg}, 33.50-99.06 \mathrm{mg} / \mathrm{kg}, 16.20-28.11 \mathrm{mg} / \mathrm{kg}$, and $50.91-89.10 \mathrm{mg} / \mathrm{kg}$ for wet season respectively. The analytical results indicated that in both wet and dry seasons some metals concentrations were above the literature levels of a typical soil, which course for concern. @ JASEM
\end{abstract}

Concern over the possible ecological effect of the increasing accumulation of metallic contaminants in the environment is growing. For this reason, the investigation of heavy metals in soil is essential since even slight changes in their concentration above the acceptable levels, whether due to natural or anthropogenic factors, can result in serious environmental and subsequent health problems. (Fangueiro et al, 2002, Sandroni and Smith 2002, Cobelo-Garcia et al, 2004). Heavy metals is a general collective term which applies to the group of metals and metalloids with atomic density greater than 4 $\mathrm{g} / \mathrm{cm}^{3}$ or 5 times or more, greater than water (Huton and Symon, 1986; Battarbee et al., 1988; Nriagu and Pacyna, 1988; Nriagu, 1989; Garbarino et al., 1995, Hawkes, 1997). To small extent heavy metals enter the body system through food, air and water and bioaccumulate over a period of time (Lenntech, 2004; UNEP/GPA, 2004). Heavy metals are basically recovered from their ores by mineral processing operations (Peplow, 1999; Lenntech, 2004; UNEP/GPA, 2004; USDOL, 2004).

The situation is even more worrisome in the developing countries where research efforts towards monitoring the environment have not been given the desired attention by the stake holders. The use of dumpsites as farm land is a common practice in urban and suburban centers in Nigeria because of the fact that decayed and composted waste enhances soil fertility (Ogunyemi et al, 2003). When agricultural soils are polluted, these metals are taken up by plants and consequently accumulate in their tissues (Trueby, 2003). Animals that graze on such contaminated plants and drink from polluted waters, as well as marine lives that breed in heavy metal polluted waters also accumulate such metals in their tissues and milk if lactating (Habashi, 1992; Garbarino et al., 1995; Horsfall and Spiff, 1999; Peplow, 1999). Municipal waste contains such heavy metals as $\mathrm{Pb}$, $\mathrm{Co}, \mathrm{Hg}, \mathrm{Mn}, \mathrm{As}, \mathrm{Fe}$, and so on which end up in the soil as the sink when they are leached out from the dump sites. Contamination of the environment by heavy metals is viewed as an international problem because of the effects on the ecosystem in most countries. In Nigeria, the situation is no better by the activities of most industries and populace towards waste disposal and management which usually leads to the increasing level of pollution of the environment. The main purpose of this study therefore is to investigate whether the trend of heavy metals concentration at Yauri abattoir dumping site (which is located at the river Niger side) soil is sufficient enough to affect the environment as well as the health of the inhabitants of the area who depend on river Niger, as their source of domestic and drinking water.

\section{MATERIALS AND METHODS}

Eight sampling spots at a distance of $50 \mathrm{~m}$ from each other were mapped out for soil samples collection within the sampling site. Samples were collected during the rainy season of 2007 and in the dry season 2008 using clean stainless steel trowel from $0-15 \mathrm{~cm}$ depth. A soil sample for each season to serve as control was also collected from a site about $50 \mathrm{~m}$ away from the dump site. The $\mathrm{pH}$ of the soil samples was determined with Orion Research Analog pH meter/model 301 according to standard analytical methods. Organic matter was determined using the 
chromic acid oxidation method (Walkey and Black, 1934).

A well-mixed sample of $0.5-1.0 \mathrm{~g}$ was weighed into a $120 \mathrm{ml}$ Teflon PFA microwave digestion vessel and $10 \mathrm{ml}$ of concentrated $\mathrm{HNO}_{3}$ was added (EPA Method 3051). The samples were capped and weighted to determine possible acid loss during digestion. The samples then were digested in a CEM 2000 Microwave digestor at 100 pounds per square inch (PSI) for $5.5 \mathrm{~min}$ (CEM Corporation, Matthews, NC).They were then filtered through Whatman 42 Filters and transferred to $100 \mathrm{ml}$ volumetric flasks. Samples with weight loss of greater than $10 \%$ were redigested. The digested samples were analyzed for heavy metals using Atomic Absorption. Spectrophotometer, Alpha Star Model 4 \{Chem. Tech. Analytical $\}$ at the Center for Energy Research and Development of the Obafemi Awolowo University Ile- Ife, Nigeria. Instrumental conditions are as reported earlier (Oladipo et al; 2005).

\section{RESULT AND DISCUSSION}

Table 1, shows soil properties determined in this study. Sand and clay fractions were dominant in the dumpsite soil and control; soil $\mathrm{pH}$ of the dumpsite soil was neutral with higher organic matter content in the wet than dry season. While the soil $\mathrm{pH}$ for control showed a slightly acidic level with low organic matter content, student's T- test showed that the soil texture, $\mathrm{pH}$ and organic matter content of the dump site soil were not significantly different from one season to another. The $\mathrm{pH}$ of the dump site soil in both the dry season (6.9) and the wet season (7.1) was higher than the control (6.4) and (6.3) respectively. This was probably due to the presence of collapsed cement structures that are dump in the site, and cement blocks that were used in fencing the site that serve as the source of Calcium Carbonate $\left(\mathrm{CaCO}_{3}\right)$ buffer in addition to rainfall event during the wet season which dilutes the soil solution the more, thus leading to $\mathrm{PH}$ increase. At low $\mathrm{pH}$ metals are more soluble in the soil solution; hence, toxicity problems are more severe in acidic soils than in alkaline soil.

Table: 1 Soil Properties

\begin{tabular}{lcccccc}
\hline Soil & $\begin{array}{c}\text { Soil } \\
\text { Depth (CM) }\end{array}$ & \%sand & \%silt & \%clay & pH & \%organic matter \\
\hline Wet season & $0-15$ & 50.92 & 13.76 & 35.32 & 7.1 & 7.42 \\
Control & $0-15$ & 54.63 & 13.21 & 32.16 & 6.3 & 1.03 \\
Dry season & $0-15$ & 52.85 & 11.92 & 35.20 & 6.9 & 5.06 \\
\hline Control & $0-15$ & 52.02 & 10.85 & 37.13 & 6.4 & 0.69 \\
\hline
\end{tabular}

Higher organic matter content in the dump site soil than that of the control may be due to decomposition and composting processes of the animals waste (which include animal's dung, body parts and blood), plants/vegetable matter and polymer or plastic materials (as the site is also used as a municipal solid waste dump) and also washed away agricultural chemicals (pesticides, insecticides and herbicides) that passed through the dump site before entering the main river from the farms and town. Organic matter plays an important role in soil structure, water retention, Cation exchange and in the formation of complexes (Alloway and Ayres, 1997).

Tables 2 and 3 represent the heavy metals concentrations in the dump site soils in both dry and wet seasons respectively. In all the metals, the concentrations of metals in the dry season were higher than those in the wet season. This might be due to the run off effect that is capable of removing heavy metals from the dump site and the effect of rainfall which may facilitate the dilution of soil solution during the wet season.
During the dry season, dumping and burning of wastes are a common practice at the dumping site. This and more intense evaporation in the dry season makes soil solution more concentrated. The sequence of metal concentrations in the dump site soil was $\mathrm{Fe}>\mathrm{Mn}>\mathrm{Ni}>\mathrm{Cr}>\mathrm{Cu}>\mathrm{Zn}>\mathrm{Pb}>\mathrm{Co}$ in the dry season while it was $\mathrm{Fe}>\mathrm{Mn}>\mathrm{Ni}>\mathrm{Cr}>\mathrm{Zn}>\mathrm{Cu}>\mathrm{Pb}>\mathrm{Co}$, in the wet season. The heavy metal concentrations in soil for both dry and wet seasons are higher than those for control. Generally higher mean heavy metal concentrations were recorded in soil during the dry season than in the wet season, and in both seasons Co has the least concentration of 13.12 and 10.13 respectively while $\mathrm{Fe}$ has the highest with 4130.02 and 3671.14 respectively. The heavy metals levels in both the dump site soil and controls were above the background levels range for farming, (Brady,1984); The relatively high values for control samples might be as a result of the site being experiencing heavy metals accumulation due to run offs from the city during raining season, as there are no appropriate sewage and municipal waste management system.. Some heavy metals like $\mathrm{As}, \mathrm{Cd}$ and $\mathrm{Pb}$ have been

* Corresponding author: Yahaya, M.I. 
reported to have no known bio-importance in human biochemistry and physiology and consumption even at very low concentrations can be toxic (Holum,
1983; Fosmire, 1990; McCluggage, 1999; Ferner, 2001, EU,2002; Nolan, 2003; Young, 2005).

Table 5. Correlation Coefficient of Metals Concentration in Soil for both Wet and Dry Seasons

\begin{tabular}{lllllllll}
\hline Metals & $\mathrm{Co}$ & $\mathrm{Cr}$ & $\mathrm{Cu}$ & $\mathrm{Fe}$ & $\mathrm{Mn}$ & $\mathrm{Ni}$ & $\mathrm{Pb}$ & $\mathrm{Zn}$ \\
\hline Correlation Coefficient & 0.56 & 0.47 & 0.38 & 0.85 & 0.66 & 0.98 & 0.87 & 0.76 \\
\hline \multicolumn{7}{c}{$\mathrm{P}<0.01$} \\
\hline
\end{tabular}

TABLE 2: Average Level of Heavy Metals in the Dump Site Soil in the Dry Season (mg/kg) *Source: Brady (1984); S=Sampling point and Values in Parentheses indicate control

\begin{tabular}{|c|c|c|c|c|c|c|c|c|}
\hline Sampling site & $\mathrm{Co}$ & $\mathrm{Cr}$ & $\mathrm{Cu}$ & $\mathrm{Fe}$ & $\mathrm{Mn}$ & $\mathrm{Ni}$ & $\mathrm{Pb}$ & $\mathrm{Zn}$ \\
\hline $\mathrm{S} 1$ & $\begin{array}{c}25.71 \pm 0.03 \\
(10.12 \pm 0.10)\end{array}$ & $\begin{array}{l}102.50 \pm 0.01 \\
(52.36 \pm 0.03)\end{array}$ & $\begin{array}{c}76.01 \pm 0.02 \\
(24.70 \pm 0.10)\end{array}$ & $\begin{array}{c}4130.02 \pm 3.12 \\
(5200.60 \pm 0.00)\end{array}$ & $\begin{array}{c}608.11 \pm 0.05 \\
(410.34+0.10)\end{array}$ & $\begin{array}{l}107.13 \pm 0.03 \\
(22.07 \pm 0.01)\end{array}$ & $\begin{array}{c}30.09 \pm 0.06 \\
(18.63 \pm 0.02)\end{array}$ & $\begin{array}{c}92.50 \pm 0.06 \\
(63.10 \pm 0.03)\end{array}$ \\
\hline S3 & $\begin{array}{l}20.02 \pm 0.01 \\
(9.89 \pm 0.06)\end{array}$ & $\begin{array}{l}100.03 \pm 2.00 \\
(91.01 \pm 0.02)\end{array}$ & $\begin{array}{c}68.18 \pm 12.6 \\
(36.15 \pm 1.10)\end{array}$ & $\begin{array}{c}4000.09+1.13 \\
(2740 \pm 0.64)\end{array}$ & $\begin{array}{c}290.32 \pm 0.02 \\
(270.10 \pm 0.87)\end{array}$ & $\begin{array}{c}81.17 \pm 1.04 \\
(64.03 \pm 1.17)\end{array}$ & $\begin{array}{c}19.07 \pm 1.11 \\
(18.64 \pm 1.05)\end{array}$ & $\begin{array}{c}90.13 \pm 0.02 \\
(87.93 \pm 1.15)\end{array}$ \\
\hline S4 & $\begin{array}{c}21.54 \pm 1.00 \\
(10.01 \pm 0.03)\end{array}$ & $\begin{array}{c}86.11 \pm 0.13 \\
(89.23 \pm 0.05)\end{array}$ & $\begin{array}{c}96.13 \pm 0.26 \\
(41.22 \pm 0.05)\end{array}$ & $\begin{array}{c}3630.02 \pm 1.11 \\
(4123.16 \pm 0.83)\end{array}$ & $\begin{array}{c}463.20 \pm 0.04 \\
(400.00 \pm 1.17)\end{array}$ & $\begin{array}{c}93.00 \pm 1.00 \\
(67.15 \pm 0.23)\end{array}$ & $\begin{array}{c}28.13 \pm 0.06 \\
(23.09 \pm 0.30)\end{array}$ & $\begin{array}{c}66.09 \pm 1.07 \\
(59.71 \pm 0.03)\end{array}$ \\
\hline S5 & $\begin{array}{l}30.02+ \pm 0.62 \\
(10.00 \pm 0.04)\end{array}$ & $\begin{array}{c}93.25 \pm 0.04 \\
(76.30 \pm 0.23)\end{array}$ & $\begin{array}{c}71.11 \pm 0.05 \\
(38.03 \pm 0.12)\end{array}$ & $\begin{array}{c}3790.10+0.32 \\
(5026.04 \pm 0.19)\end{array}$ & $\begin{array}{c}372.11 \pm 1.03 \\
(369.04 \pm 0.54)\end{array}$ & $\begin{array}{c}72.63 \pm 0.02 \\
(70.02 \pm 0.13)\end{array}$ & $\begin{array}{c}15.60 \pm 1.02 \\
(14.30 \pm 0.11)\end{array}$ & $\begin{array}{c}82.16 \pm 0.03 \\
(76.15 \pm 0.11)\end{array}$ \\
\hline S6 & $\begin{array}{c}14.33 \pm 0.07 \\
(10.13 \pm 1.02)\end{array}$ & $\begin{array}{c}69.17 \pm 0.14 \\
(56.01 \pm 0.06)\end{array}$ & $\begin{array}{c}86.17 \pm 0.75 \\
(34.19 \pm 0.36)\end{array}$ & $\begin{array}{c}3841.04+1.13 \\
(5000.13 \pm 0.09)\end{array}$ & $\begin{array}{c}300.30 \pm 0.12 \\
(270.10 \pm 0.70)\end{array}$ & $\begin{array}{c}52.31 \pm 0.07 \\
(47.91 \pm 0.34)\end{array}$ & $\begin{array}{c}22.07 \pm 0.04 \\
(20.69 \pm 0.19)\end{array}$ & $\begin{array}{c}80.10 \pm 0.05 \\
(74.69 \pm 0.09)\end{array}$ \\
\hline S7 & $\begin{array}{l}16.59 \pm 0.84 \\
(7.37 \pm 1.13)\end{array}$ & $\begin{array}{c}59.14 \pm 0.21 \\
(48.16 \pm 0.30)\end{array}$ & $\begin{array}{c}59.32 \pm 0.07 \\
(30.26 \pm 0.14)\end{array}$ & $\begin{array}{c}3570.13 \pm 0.07 \\
(4782.46 \pm 0.42)\end{array}$ & $\begin{array}{c}263.01 \pm 0.16 \\
(252.19 \pm 1.09)\end{array}$ & $\begin{array}{c}36.21 \pm 1.16 \\
(33.42 \pm 0.55)\end{array}$ & $\begin{array}{c}20.39 \pm 0.03 \\
(19.51 \pm 0.56)\end{array}$ & $\begin{array}{c}56.31 \pm 0.02 \\
(59.10 \pm 0.08)\end{array}$ \\
\hline S8 & $\begin{array}{c}22.36+2.03 \\
(11.02 \pm 0.00)\end{array}$ & $\begin{array}{c}90.07 \pm 0.25 \\
(77.00 \pm 0.22)\end{array}$ & $\begin{array}{c}90.13 \pm 1.02 \\
(33.41 \pm 0.20)\end{array}$ & $\begin{array}{c}2569.07 \pm 0.01 \\
(4910.56 \pm 1.93)\end{array}$ & $\begin{array}{c}412.60 \pm 0.07 \\
(349.10 \pm 0.03)\end{array}$ & $\begin{array}{c}60.33 \pm 0.04 \\
(42.10 \pm 0.10)\end{array}$ & $\begin{array}{c}29.02 \pm 1.01 \\
(16.72 \pm 0.63)\end{array}$ & $\begin{array}{c}70.40 \pm 0.06 \\
(63.13 \pm 1.14)\end{array}$ \\
\hline $\begin{array}{c}\text { Elemental } \\
\text { Concentration } \\
\text { of a typical } \\
\text { Soil * }\end{array}$ & 9.1 & 54 & 25 & 26000 & 550 & 19 & 19 & 60 \\
\hline
\end{tabular}

Table 3:-Average Level of Heavy Metals in the Dump Site Soil in the Wet Season (mg/kg)

\begin{tabular}{|c|c|c|c|c|c|c|c|c|}
\hline $\begin{array}{c}\text { Sampling } \\
\text { Site }\end{array}$ & $\mathrm{Co}$ & $\mathrm{Cr}$ & $\mathrm{Cu}$ & $\mathrm{Fe}$ & $\mathrm{Mn}$ & $\mathrm{Ni}$ & $\mathrm{Pb}$ & $\mathrm{Zn}$ \\
\hline \multirow[t]{2}{*}{$\mathrm{S} 1$} & $20.63+0.07$ & $87.12+0.03$ & $62.10+0.01$ & $2370.19 \pm 1.01$ & $511.07 \pm 0.03$ & $99.06+0.01$ & $28.11 \pm 0.02$ & $79.62+0.13$ \\
\hline & $(11.62 \pm 0.03)$ & $(50.13 \pm 0.01)$ & $(21.36 \pm 0.12)$ & $(3201.14 \pm 0.03)$ & $(501.32 \pm 1.02)$ & $(36.20 \pm 0.03)$ & $22.31 \pm 0.01)$ & $(64.25 \pm 0.04)$ \\
\hline \multirow[t]{2}{*}{$\mathrm{S} 2$} & $12.92 \pm 0.41$ & $51.66 \pm 0.2$ & $62.31 \pm 0.01$ & $3110.76 \pm 0.03$ & $561.03 \pm 0.12$ & $86.17 \pm 0.04$ & $20.17 \pm 0.07$ & $71.30 \pm 1.03$ \\
\hline & $(10.76 \pm 0.10)$ & $(48.32 \pm 0.05)$ & $(50.13 \pm 0.55)$ & $(2640.01 \pm 0.02)$ & $(497.14 \pm 0.01)$ & $(80.03 \pm 1.12)$ & $(19.07 \pm 0.11)$ & $(66.13 \pm 0.05)$ \\
\hline \multirow[t]{2}{*}{$\mathrm{S} 3$} & $10.13 \pm 0.03$ & $68.01 \pm 0.13$ & $51.93 \pm 0.03$ & $2990.16 \pm 0.14$ & $273.20 \pm 0.01$ & $78.71 \pm 1.11$ & $16.39 \pm 0.04$ & $89.10 \pm 0.06$ \\
\hline & $(8.92 \pm 0.04)$ & $(64.52 \pm 1.21)$ & $(40.16 \pm 0.01)$ & $(2005.23 \pm 0.02)$ & $(189.45 \pm 0.09)$ & $(69.36 \pm 0.01)$ & $(15.04 \pm 1.01)$ & $(74.15 \pm 0.15)$ \\
\hline \multirow[t]{2}{*}{ S4 } & $21.10+0.02$ & $78.10 \pm 0.70$ & $57.72 \pm 0.13$ & $2690.20 \pm 0.12$ & $436.11 \pm 0.13$ & $90.21 \pm 0.06$ & $25.90 \pm 1.03$ & $64.29 \pm 1.04$ \\
\hline & $(9.0 \pm 1.12)$ & $(70.11 \pm 0.34)$ & $(48.86 \pm 0.05)$ & $(2201.35 \pm 0.05)$ & $(400.19 \pm 1.35)$ & $(74.50 \pm 1.09)$ & $(0.04 \pm 0.09)$ & $(52.17 \pm 0.09)$ \\
\hline \multirow[t]{2}{*}{ S5 } & $18.14+1.13$ & $80.00 \pm 0.04$ & $69.29 \pm 0.16$ & $3530.07 \pm 0.02$ & $252.03 \pm 1.01$ & $70.69 \pm 0.12$ & $16.20+0.06$ & $80.41 \pm 0.01$ \\
\hline & $(16.66 \pm 0.06)$ & $(67.42 \pm 0.48)$ & $(51.36 \pm 0.09)$ & $(2978.16 \pm 0.06)$ & $(330.21 \pm 0.04)$ & $(68.10 \pm 0.05)$ & $(14.37 \pm 0.04)$ & $(71.90 \pm 1.04)$ \\
\hline \multirow[t]{2}{*}{ S6 } & $16.12 \pm 0.02$ & $86.23 \pm 1.07$ & $61.72 \pm 0.05$ & $3671.14 \pm 0.06$ & $279.56 \pm 0.03$ & $49.36 \pm 0.05$ & $21.01 \pm 1.05$ & $78.52+0.06$ \\
\hline & $(15.01 \pm 0.01)$ & $(79.30 \pm 1.32)$ & $(45.66 \pm 1.01)$ & $(3062.51 \pm 0.09)$ & $(265.10 \pm 0.49)$ & $(40.00 \pm 0.02)$ & $(18.13 \pm 0.01)$ & $(67.36 \pm 1.00)$ \\
\hline \multirow[t]{2}{*}{ S7 } & $11.92+1.03$ & $49.96 \pm 0.03$ & $49.12 \pm 0.01$ & $2911.10 \pm 0.05$ & $249.72 \pm 1.15$ & $33.50 \pm 0.16$ & $17.35 \pm 0.02$ & $50.91+1.01$ \\
\hline & $(09.61 \pm 0.05)$ & $(50.02+0.01)$ & $(38.50+1.09)$ & $(2306.19 \pm 0.26)$ & $(203.51+0.02)$ & $(28.14 \pm 0.04)$ & $(15.49 \pm 0.34)$ & $(40.12+0.08)$ \\
\hline \multirow[t]{2}{*}{ S8 } & $22.76 \pm 0.16$ & $89.46 \pm 0.12$ & $73.08 \pm 1.13$ & $2330.02 \pm 0.16$ & $368.98 \pm 0.04$ & $57.49 \pm 0.01$ & $23.70 \pm 0.02$ & $88.69 \pm 0.03$ \\
\hline & $(19.10 \pm 0.02)$ & $(76.19 \pm 0.14)$ & $(66.07 \pm 0.34)$ & $(2287.13 \pm 0.04)$ & $(311.72 \pm 0.08)$ & $(46.18 \pm 1.13)$ & $(20.09 \pm 0.41)$ & $(74.90 \pm 1.05)$ \\
\hline
\end{tabular}

Statistical analysis revealed that there were weak correlation between $\mathrm{Co}(\mathrm{r}=0.6), \mathrm{Cr}(\mathrm{r}=0.5)$ and $\mathrm{Cu}$ $(\mathrm{r}=0.5)$ each in both dry and wet seasons suggesting that these metals might not be from the same source.
Similar trend was observed for $\mathrm{Ni}$ and $\mathrm{Pb}(\mathrm{r}=0.5)$, $\mathrm{Cu}$ and $\mathrm{Zn}(\mathrm{r}=0.6)$ and $\mathrm{Cu}$ and $\mathrm{Pb}(\mathrm{r}=0.3)$ each in wet season and $\mathrm{Mn}$ and $\mathrm{Zn}(\mathrm{r}=0.2)$ in dry season respectively. Zero correlation was obtained when $\mathrm{Mn}$

* Corresponding author: Yahaya, M.I. 
and $\mathrm{Zn}$ (wet season) and $\mathrm{Cu}$ and $\mathrm{Zn}$ (dry season) were correlated, signifying that there is no linear correlation between these metals. But when the metals concentration in both dump soils for wet and dry seasons were correlated (Table 5), there was a perfect correlation for $\mathrm{Ni}(1)$ in both seasons, strong correlation in $\mathrm{Fe}(0.9), \mathrm{Pb}(0.9), \mathrm{Mn}(0.7)$ and $\mathrm{Zn}$ $(0.8)$ and a weak correlation in $\mathrm{Co}(0.6), \mathrm{Cr}(0.5)$ and
$\mathrm{Cu}(0.4)$. These statistical results implies that $\mathrm{Mn}, \mathrm{Ni}$, $\mathrm{Fe}, \mathrm{Pb}$, and $\mathrm{Zn}$ were from same source while $\mathrm{Co}, \mathrm{Cr}$ and $\mathrm{Cu}$ from different source.

Analytical results (Tables 2 and 3) indicated that in the wet and dry seasons, values for $\mathrm{Co}, \mathrm{Cr}, \mathrm{Cu}, \mathrm{Mn}$, $\mathrm{Ni}, \mathrm{Pb}$ and $\mathrm{Zn}$ were above the Literature levels of a typical soil (Brady,1984)

Table 4: Comparison of Metal Levels in this Study with the Levels in Some other Studies Elsewhere

\begin{tabular}{cccccc}
\hline Metals & This Study & Study in USA $^{a}$ & Study in China $^{b}$ & Study in Poland $^{c}$ & Study in India $^{d}$ \\
\hline $\mathrm{Co}$ & $13.21-30.02$ & NA & NA & NA & NA \\
$\mathrm{Cr}$ & $59.14-102.50$ & $6.59-208$ & $19.3-150$ & $3.7-75.3$ & ND -145.45 \\
$\mathrm{Cu}$ & $59.32-96.13$ & $2.86-101$ & $7.26-55.1$ & $2.0-18.0$ & $5.34-198.23$ \\
$\mathrm{Fe}$ & $2569.1-4130.0$ & NA & NA & NA & $576-16234$ \\
$\mathrm{Mn}$ & $263.01-608.11$ & $43-2532$ & $134-1740$ & $83-1122$ & NA \\
$\mathrm{Ni}$ & $36.21-107.13$ & $2.44-69.4$ & $77.3-70-9$ & $2.0-27.0$ & $343-1409$ \\
$\mathrm{~Pb}$ & $15.60-30.09$ & $4.62-55.4$ & $9.95-56.0$ & $7.1-50.1$ & ND - 623.95 \\
\hline $\mathrm{Zn}$ & $56.31-92.50$ & $12.6-183$ & $28.5-161$ & $10.5-1547$ & NA \\
\hline
\end{tabular}

${ }^{a}$ Shacklette and Boerngen (1984), ${ }^{b}$ Bradford et al (1996), ${ }^{\mathrm{c}}$ Dudka (1992). ${ }^{\mathrm{d}}$ Abida et al (2009) ND = Not Detected NA = Not Available

The high value of $\mathrm{Cr}$ conforms to a similar finding (Table 4) in US, China, Poland and India's soils. Chromium functions in mammalian glucose metabolism and appears to be essential to man and animals. $\mathrm{Cu}$ and $\mathrm{Zn}$ are essential plant micronutrients. They can also bind to soil organic matter and become unavailable to plants. In this study the high levels of $\mathrm{Cu}$ concentration in dump soil are similar to metals analysis in soil reported in US, China, and India; it differs only with that of Poland (Table 4). For $\mathrm{Zn}$ the high values are similar to findings in US, China and Poland as shown in Table 4

Higher levels of $\mathrm{Ni}$ and $\mathrm{Pb}$ are in conformity with the high concentrations obtained in other countries (Table 4).

Mn levels are higher than reported concentrations from other countries that were compared with the present work. In most soil $\mathrm{Fe}$ is present in large quantities on average between $3-5 \%$ of soil consist of $\mathrm{Fe}$, which makes it the fourth most abundant element in the earth crust. Fe levels obtained from this study are lower than those reported by Abida et al (2009) in India.

Conclusion: Levels of $\mathrm{Co}, \mathrm{Cr}, \mathrm{Cu}, \mathrm{Fe}, \mathrm{Mn}, \mathrm{Ni}, \mathrm{Pb}$, and $\mathrm{Zn}$ in Yauri Abattoir dumping site soil have been determined in this study by AAS after microwave acid digestion. The analytical results indicated that in both wet and dry seasons some heavy metals concentration were above the literature levels of a typical soil. This cause for concern as this can affect the environment as well as the health of the inhabitants of Yauri town who depend on River Niger as their source of drinking and domestic water and the dump site is situated very close to the river, which can lead to the leaching of the heavy metals and their washing away into the river by run off.

\section{REFERENCES}

Abid, B; Ramaih, M; Harikrishna, IK; Veena, K (2009). Analysis of Heavy Metals Concentrations in Soil and Litchens from various localities of Hosur Road, Bangalore, India, Ejournal of Chemistry, 6(1):13- 22.

Alloway, BJ; Ayres, DC (1997). Chemical principles of Environmental Pollution, $2^{\text {nd }}$ Edition, Blackie Academic and Professional, Chapman and Hall, London.190-242.

Battarbee, R; Anderson, N; Appleby, P; Flower, RG; Fritz, S; Haworth, E; Higgit, S; Jones, V; Kreiser, A; Munro, MA; Natkanski, J; Oldfield, F; Patrick, ST; Richardson, N; Rippey, B; Stevenson, AC (1988) Lake Acidification in The United Kingdom.ENSIS, London.

Bradford, GR; Chang, AC; Page, AL; Bakhtar, D; Frampton, JA; Wright, H (1996). Background Concentration of Trace and Major Elements in California Soils. Kearney Foundation Spec. Rep., Univ. of California, Riverside, CA.

Brady, NC (1984). The Nature and Properties of Soils. Macmillan Publishing Company Inc. New York 672.

Cobelo - Garcia, A; Prego, R; Labanderia, A (2003). Water Research, 38, 1753

Dudka, S (1992). Factor Analysis of Total Element Concentrations in Surface Soils of Poland. Science of Total Environment 121: 39- 52.

European Union (2002).Heavy Metals in Wastes. European Commission on Environment (http://ec.europa.eu/environment/waste/studies/p 
df/heavy_metalsreport.pdf). Assessed on $23^{\text {rd }}$ march 2008 .

Fanguiero, D; Bermond, A; Santos, E; Carapuca, H; Duarte, A (2002). Anal. Chim. Acta, 459: 245.

Ferner, DJ (2001) Toxicity, Heavy Metals. eMed. Jour. 2(5): 1.

Fosmire, GJ (1990). Zinc Toxicity. Am. Jour. Clin. Nutr. 51(2): 225-227.

Garbarino, JR; Hayes, H; Roth, D; Antweider, R; Brinton, TI; Taylor, H (1995). Contaminants in the Mississipi River, U. S. Geological Survey Circular 1133, Virginia,

Habashi, F (1992). Environmental Issues in the Metallurgical Industry- Progress and Problems, Environmental issues and Waste Management in Energy and Mineral Production. Balkama, Rotherdam, 1143 - 1153

Hawkes, JS. (1997). Heavy Metals Jour. Chem. Edu. 74(11): 1374

Holum, JR (1983). Elements of General and Biological Chemistry, $6^{\text {th }}$ Edition, John Wiley and Sons, N.Y. 324,326 353 and 469.

Horsfall, MN; Spiff AL (1999). Speciation of Heavy Metals in Intertidal Sediments of the Okirika River System (Nigeria), Bull. Chem. Soc. Ethiop. 13(1): $1-9$

Hutton, M; Symon, C (1986). The Quantities of Cadmium, Lead, Mercury and Arsenic Entering the U.K. Environment from Human Activities. Sci. Total Environ. 57:129 - 150.

Lenntech Water Treatment and Air Purification (2004). Water Treatment, Publish by Lenntech, Rotterdamseweg, Netherlands.

McCluggage, D (1991). Heavy Metal Poisoning, NCS Magazine, Published by The Bird Hospital, CO, U.S.A.

Nolan, K (2003).Copper Toxicity Syndrome.Jour. Orthomol. Psychiatry 12(4):270 - 282.
Nriagu, JO (1989). A Global Assessment of Natural Sources of Atmospheric Trace Metals, Nature, 338: $47-49$.

Nriagu, JO; Pacyna, J (1988). Quantitative Assessment of Worldwide Contamination of Air, Water and Soil by Trace Metals .Nature, 333: $134-139$

Ogunyemi, S; Awodoyin, RO; Opadeji, T (2003). Urban Agricultural Production: Heavy Metal Contamination of Amaranthus cruenties L. grown on domestic refuse landfill soil in Ibadan, Nigeria, Emir, Jour. Agric. Sci, 87-94.

Oladipo, AA; Oluyemi, EA; Tubosun, IA; Fasasi, MK (2005). Chemical Examination of Ikogosi Warm Spring in South Western Nigeria, Jour. Appl. Sci 5(1) 75-79

Peplow, D (1999). Environmental Impacts of Mining in Eastern Washington, Centre for Water and Watershed Studies Fact Sheet, University of Washington. Seattle.

Sandroni, V; Smith, CM (2002). Anal. Chim. Acta. 468:335.

Shacklette, HT; Boerngen, JG (1984). Element Concentrations in Soils and other Surficial Materials of the Conterminous United State. USGS Professional Paper 1270 U.S. Gov. Print. Office, Washington D.C.

Trueby, P (2003). Impact of Heavy Metals on Forest Trees from Mining Areas. In: International Conference on Mining and the Environment 11, Sudbury, Ontario, Canada.

United Nations Environmental Protection/Global Program of Action (2004). Why the Marine Environment needs Protection from Heavy Metals. UNEP/GPA Coordination Office.

United States Department of Labour (2004). Occupational Safety and Health Administration (OSHA); Safety and Health Topics: Heavy Metals. USDOL Publication, Washington, D.C.

Young, RA (2005). Toxicity Profiles: Toxicity Summary for Cadmium: Risk Assessment Information System, University of Tennessee. 